\title{
Two novel Co(II) complexes with two different Schiff bases: inhibiting growth of human skin cancer cells
}

\author{
Y.-J. Xiao ${ }^{1,2}$, Q.-C. Diao ${ }^{2}$, Y.-H. Liang ${ }^{3}$ and K. Zeng ${ }^{1}$ \\ ${ }^{1}$ Department of Dermatology, Nanfang Hospital, Southern Medical University, Guangzhou, Guangdong, China \\ ${ }^{2}$ Department of Dermatology, The Chongqing Hospital of Traditional Chinese Medicine \\ (The First People's Hospital of Chongqing City), Chongqing, China \\ ${ }^{3}$ Department of Dermatology, Shenzhen Hospital, Southern Medical University, Shenzhen, Guangdong, China
}

\begin{abstract}
Using two flexible Schiff bases, $\mathrm{H}_{2} \mathrm{~L}_{1}$ and $\mathrm{H}_{2} \mathrm{~L}_{2}$, two new cobalt II (Co(II))-coordination compounds, namely, $\mathrm{Py}_{3} \mathrm{CoL}_{1}(1)$ and $\mathrm{Py}_{3} \mathrm{CoL}_{2}$ (2) (Py=pyridine, $\left.\mathrm{L}_{1}=3,5-\mathrm{ClC}_{6} \mathrm{H}_{2}(\mathrm{O}) \mathrm{C}=\mathrm{NC}_{6} \mathrm{H}_{3}(\mathrm{O})-4-\mathrm{NO}_{2}, \mathrm{~L}_{2}=3,5-\mathrm{BrC}_{6} \mathrm{H}_{2}(\mathrm{O}) \mathrm{C}=\mathrm{NC}_{6} \mathrm{H}_{3}(\mathrm{O})-4-\mathrm{NO}_{2}\right)$ have been synthesized under solvothermal conditions. Single crystal X-ray structural analysis revealed that compounds 1 and 2 are both sixcoordinate in a distorted octahedral geometry, and the 1D chain structure was formed by the $\pi \ldots \pi$ and $\mathrm{C}-\mathrm{H} \ldots \mathrm{O}$ interactions or $\mathrm{C}-\mathrm{H}$... Cl interaction. The in vitro antitumor activities of 1,2 and their corresponding organic ligands $P y, L_{1}$, and $L_{2}$ were studied and evaluated, in which three human skin cancer cell lines (A-431, HT-144 and SK-MEL-30) were used in the screening tests.
\end{abstract}

Key words: Schiff bases; Coordination compound; Antitumor activity

\section{Introduction}

Cancer is a proliferation disorder disease with apoptosis obstacles $(1,2)$. It strikes more than one-third of the world's population and causes over $20 \%$ of all deaths (3). Standard cancer treatment protocols include surgery, radiotherapy and chemotherapy (4). Unfortunately, chemotherapy is not effective in treating cancers associated with innate resistance to apoptosis and/or acquired resistance to drugs during treatment. Discovery of novel effective anticancer medicines is therefore of great importance (5).

Cobalt complexes with Schiff bases have received considerable attention in the fields of coordination chemistry and biological chemistry (6). Cobalt functions as the active site of hydrolytic enzymes, such as carboxypeptidase and carbonic anhydrase where it is in a hard-donor coordination environment of nitrogen and oxygen (7). Cobalt has been recognized as an important cofactor in biological molecules, either as a structural template in protein folding or as a Lewis acid catalyst that can readily adopt four-, five-, or six-coordination $(7,8)$. The cobalt (Co) complexes with the Schiff bases derived from salicylaldehyde and its analogues have been extensively studied (9). In this work, two new $\mathrm{Co}(\mathrm{II})$ complexes, $\mathrm{Py}_{3} \mathrm{CoL}_{1}$ (1) and $\mathrm{Py}_{3} \mathrm{CoL}_{2}$ (2) (Figure 1) (Py=pyridine, $\mathrm{L}_{1}=3,5-\mathrm{ClC}_{6} \mathrm{H}_{2}(\mathrm{O})$ $\mathrm{C}=\mathrm{NC}_{6} \mathrm{H}_{3}(\mathrm{O})-4-\mathrm{NO}_{2}, \mathrm{~L}_{2}=3,5-\mathrm{BrC}_{6} \mathrm{H}_{2}(\mathrm{O}) \mathrm{C}=\mathrm{NC}_{6} \mathrm{H}_{3}(\mathrm{O})-4-\mathrm{NO}_{2}$ ), were solvothermally prepared by employment of two different base ligands and their antitumor activities were then evaluated.

\section{Material and Methods}

\section{Apparatus and materials}

All starting materials and reagents used in this research were obtained commercially and used without further purification. Element analyses $(\mathrm{C}, \mathrm{H}$, and $\mathrm{N})$ were determined with an elemental Vario EL III analyzer (Elementar, Germany). Single-crystal X-ray diffraction data for compounds 1 and 2 were recorded on Mercury CCD diffractometer (Bruker Optics, Germany). The melting points were taken on a XT-4 micro melting apparatus (Ledon, China), and the thermometer was uncorrected. Three human skin cancer cell lines (A-431, HT-144 and SK-MEL-30) were purchased from Sigma-Aldrich (USA).

Synthesis and characterization of compounds 1 and 2

A mixture of $\mathrm{CoCl}_{2}(1.0 \mathrm{mmol}, 0.130 \mathrm{~g})$, and 3,5dichlorosalicylaldehyde-2-amino-4-nitrophenol Shiff base $\left(\mathrm{H}_{2} \mathrm{~L}_{1}, 1.0 \mathrm{mmol}, 0.327 \mathrm{~g}\right)$ were mixed in $25 \mathrm{~mL}$ methanol. After heating and dissolving in air, $10 \mathrm{~mL}$ methanol solution of $\mathrm{CoCl}_{2}(50 \mathrm{mM})$ was added to the reaction flask. Most of the solvent was removed by rotary evaporators after $2 \mathrm{~h}$ of reaction. Then, pyridine was dropped to dissolve, and the 


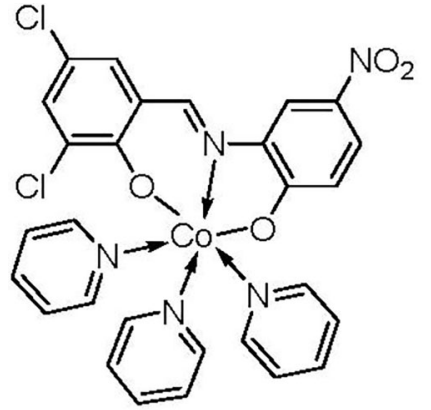

1

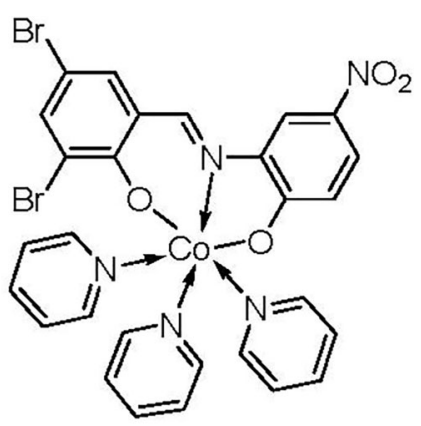

Figure 1. Scheme representation of compounds $\mathrm{Py}_{3} \mathrm{CoL}_{1}$ (1) and $\mathrm{Py}_{3} \mathrm{CoL}_{2}(2)$. solution continued to reflux for $2 \mathrm{~h}$. The solution was cooled down to room temperature and filtered and the brown crystals of solution 1 were obtained. Analytical characteristics found for compound $1\left(\mathrm{C}_{28} \mathrm{H}_{21} \mathrm{Cl}_{2} \mathrm{CoN}_{5} \mathrm{O}_{4}\right)$ were: $\mathrm{C}$, 54.18; H, 3.39; N, 11.30\%. Calculate: C, 54.13; H, 3.41; N, $11.27 \%$.

The synthesis method for compound 2 was similar to that of compound 1. Analytical characteristics found for compound $2\left(\mathrm{C}_{28} \mathrm{H}_{21} \mathrm{Br}_{2} \mathrm{CoN}_{5} \mathrm{O}_{4}\right)$ were: $\mathrm{C}, 47.40 ; \mathrm{H}, 3.00$; N, $9.85 \%$. Calculate: C, 47.35; H, 2.98; N, 9.86\%.

\section{Crystal structure determination}

Structural measurement was performed on the computer-controlled Mercury CCD diffractometer with graphite-monochromated Mo- $K \alpha$ radiation $(\lambda=0.71073 \AA$ ) at $T=293$ (2) K. Absorption correction was made using the SADABS (Bruker AXS Inc., USA) program. The structure was solved using the direct method and refined by fullmatrix least-squares methods on $F^{2}$ using the SHELXS-97 program package (10). Crystallographic data and structural refinements for compounds 1 and 2 are summarized in Table 1.

CCDC numbers for compounds 1 and 2 contain the supplementary crystallographic data for this paper. These data can be obtained free of charge via http://www.ccdc.cam. ac.uk/conts/retrieving.html (or from the CCDC, 12 Union Road, Cambridge CB2 1EZ, UK; Fax: +44-1223-336033; E-mail: E-mail: deposit@ccdc.cam.ac.uk)

\section{Antitumor activity}

Stock solutions of 1, 2 and their corresponding organic ligands $P y, L_{1}$ and $L_{2}$ were prepared in DMSO and kept at $-20^{\circ} \mathrm{C}$. Appropriate dilutions of the compounds were freshly prepared just prior to the assays. Final concentrations of DMSO did not interfere with the cell growth.

Three human skin cancer cell lines (A-431, HT-144 and SK-MEL-30) grown as monolayer were routinely maintained in RPMI-1640 medium supplemented with 5\% heat inactivated FBS, $2 \mathrm{mM}$ glutamine and antibiotics (penicillin $100 \mathrm{U} / \mathrm{mL}$, streptomycin $100 \mu \mathrm{g} / \mathrm{mL}$ ), at $37^{\circ} \mathrm{C}$ in a humidified atmosphere containing $5 \% \quad \mathrm{CO}_{2}$. Exponentially growing cells were obtained by plating $1.5 \times 10^{5}$ cells $/ \mathrm{mL}$ for A-431
Table 1. Crystal data and structure refinement for $\mathrm{Py}_{3} \mathrm{CoL}_{1}$ (1) and $\mathrm{Py}_{3} \mathrm{CoL}_{2}(2)$

\begin{tabular}{lcc}
\hline & 1 & 2 \\
\hline Formula & $\mathrm{C}_{28} \mathrm{H}_{21} \mathrm{Cl}_{2} \mathrm{CoN}_{5} \mathrm{O}_{4}$ & $\mathrm{C}_{28} \mathrm{H}_{21} \mathrm{Br}_{2} \mathrm{CoN}_{5} \mathrm{O}_{4}$ \\
$M r$ & 621.33 & 710.25 \\
Temperature/K & $296(2)$ & $296(2)$ \\
Crystal system & Triclinic & Triclinic \\
Space group & $P \mathrm{~T}$ & $P \mathrm{~T}$ \\
$a / \AA$ & $8.8780(13)$ & $8.8470(7)$ \\
$b / \AA$ & $9.0856(13)$ & $9.1799(8)$ \\
$c / \AA$ & $17.703(3)$ & $18.0141(15)$ \\
$\alpha /^{\circ}$ & $104.445(2)$ & $104.335(1)$ \\
$\beta /{ }^{\circ}$ & $92.184(2)$ & $91.368(1)$ \\
$\gamma /{ }^{\circ}$ & $99.919(2)$ & $99.064(1)$ \\
$V / \AA^{3}$ & $1357.2(3)$ & $1396.7(2)$ \\
$Z$ & 2 & 2 \\
$D_{\text {calc }} / \mathrm{g} \cdot \mathrm{cm}^{-3}$ & 1.520 & 1.689 \\
$\mu($ Mo K $\alpha) / \mathrm{mm}^{-1}$ & 0.874 & 3.519 \\
$\theta$ range ${ }^{\circ}$ & 2.35 to 28.03 & 2.32 to 25.99 \\
Reflections collected & 17,238 & 15,294 \\
No. unique data $[R($ int $)]$ & $6459[0.0262]$ & $5441[0.0232]$ \\
No. data with $/ \geqslant 2 \sigma(I)$ & 4,846 & 4,122 \\
$R_{1}$ & 0.0391 & 0.0328 \\
$\omega R_{2}($ all data) & 0.1058 & 0.0836 \\
$\mathrm{CCDC}$ & 960,791 & 960,795 \\
\hline & &
\end{tabular}

and HT-144 and $0.75 \times 10^{4}$ cells/mL for SK-MEL-30, followed by $24 \mathrm{~h}$ of incubation. The effect of the vehicle solvent (DMSO) on the growth of these cell lines was evaluated in all the experiments by exposing untreated control cells to the maximum concentration $(0.5 \%)$ of DMSO used in each assay.

\section{Results and Discussion}

\section{Molecular structure}

The crystal structure determined by single-crystal X-ray diffraction showed that 1 and 2 both crystallize in the triclinic system, space group $P$ I. The asymmetric unit 
comprises one $\mathrm{Co}(\mathrm{II})$ atom, three pyridine molecules, one 3,5-dichlorosalicylaldehyde-2-amino-4-nitrophenol or 3,5-dibromosalicylaldehyde-2-amino-4-nitrophenol Shiff base, respectively.

As shown in Figures $2 \mathrm{~A}$ and $3 \mathrm{~A}$, the central Co1 atom is six-coordinate in a distorted octahedral geometry and is surrounded by two oxygen atoms (O1 and $\mathrm{O} 2$ ) and one amino nitrogen atom (N1) from the ligand, and three nitrogen atoms (N3, N4, and N5) from three different pyridines. The axes positions were occupied by two nitrogen atoms (N1 and N4 for 1; N1 and N5 for 2) from
Shiff base ligand (3,5-dichlorosalicylaldehyde-2-amino-4nitrophenol for 1; 3,5-dibromosalicylaldehyde-2-amino-4nitrophenol for 2) and one pyridine molecule, respectively. The angle of N1-Co1-N4 and N1-Co1-N5 is $173.94^{\circ}$ and $173.92^{\circ}$, respectively, which obviously deviates from linear angle $180^{\circ}$. The equatorial positions were occupied by four atoms (O1, O2, N3 and N5 for 1; O1, O2, N3 and N4 for 2). The bond lengths and bond angles between the four atoms in the equatorial plane and the center of the Co1 atom are also different [for 1, Co1-O1=2.0116 (14) $\AA$, Co1-O2=2.0609 (15) $\AA$, Co1-N3=2.2210 (18) $\AA$, Co1-
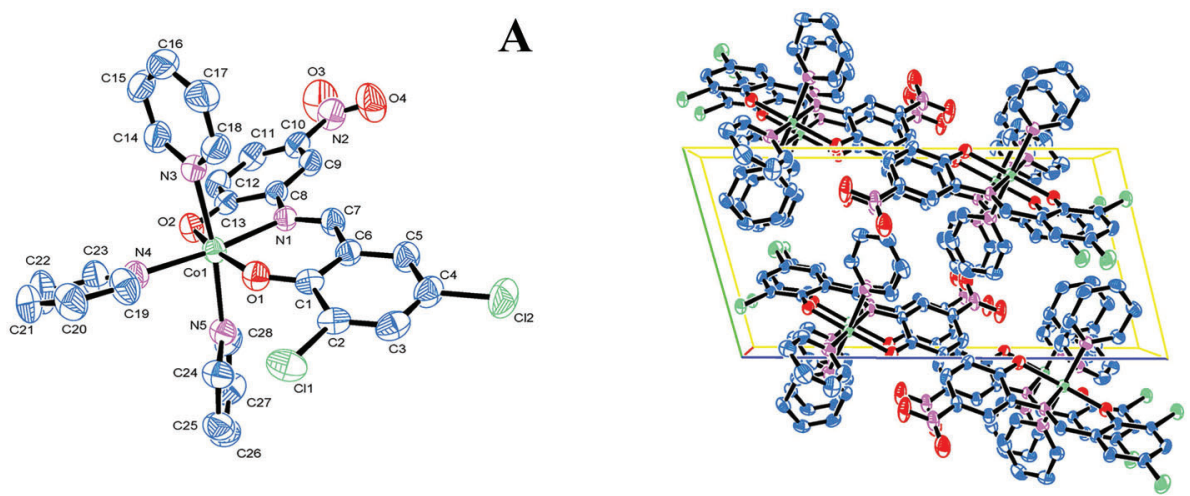

B

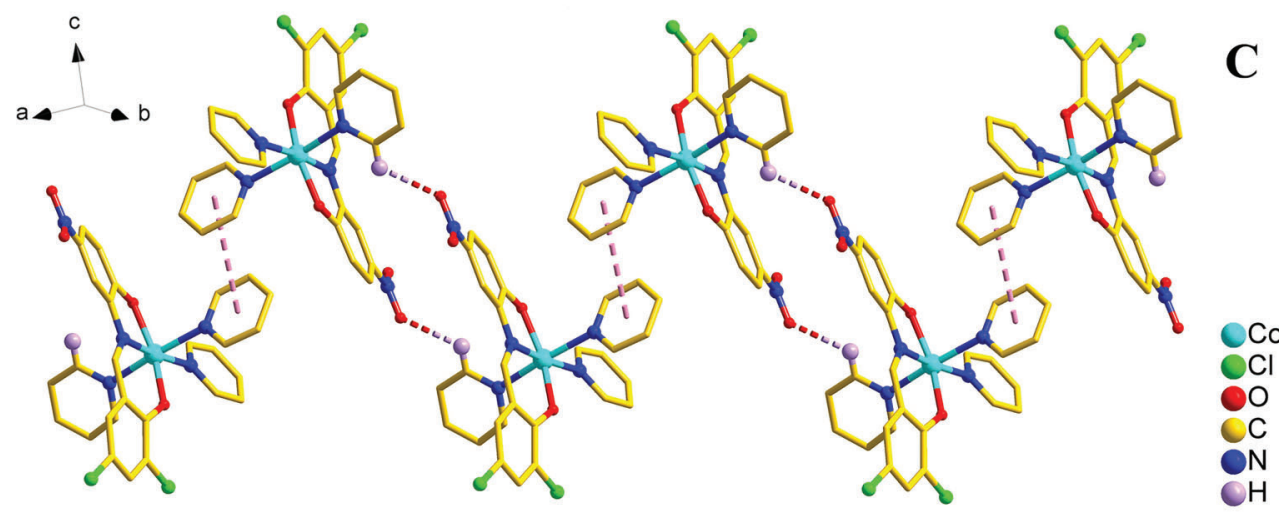

$\mathbf{A}$

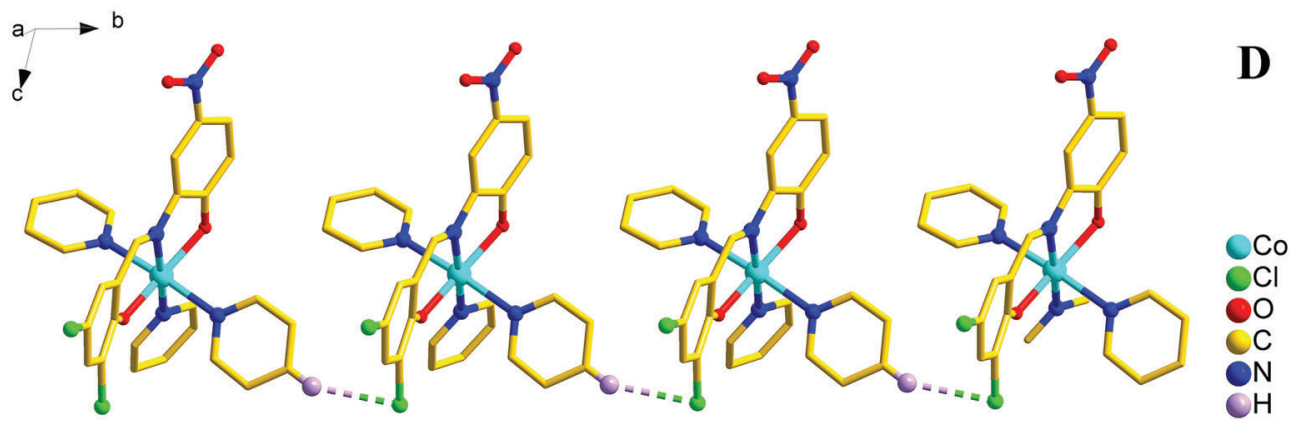

Figure 2. $A$, Molecular structure of compound $1\left(\mathrm{Py}_{3} \mathrm{CoL}_{1}\right) ; B$, packing of compound 1 in unit cell; $C$, $1 \mathrm{D}$ infinite chain structure of compound 1 was formed by the $\pi \ldots \pi$ and $\mathrm{C}-\mathrm{H} \ldots \mathrm{O}$ interactions; $D, 1 \mathrm{D}$ infinite chain structure of compound 1 was formed by the $\mathrm{C}-\mathrm{H} \ldots \mathrm{Cl}$ interactions. 

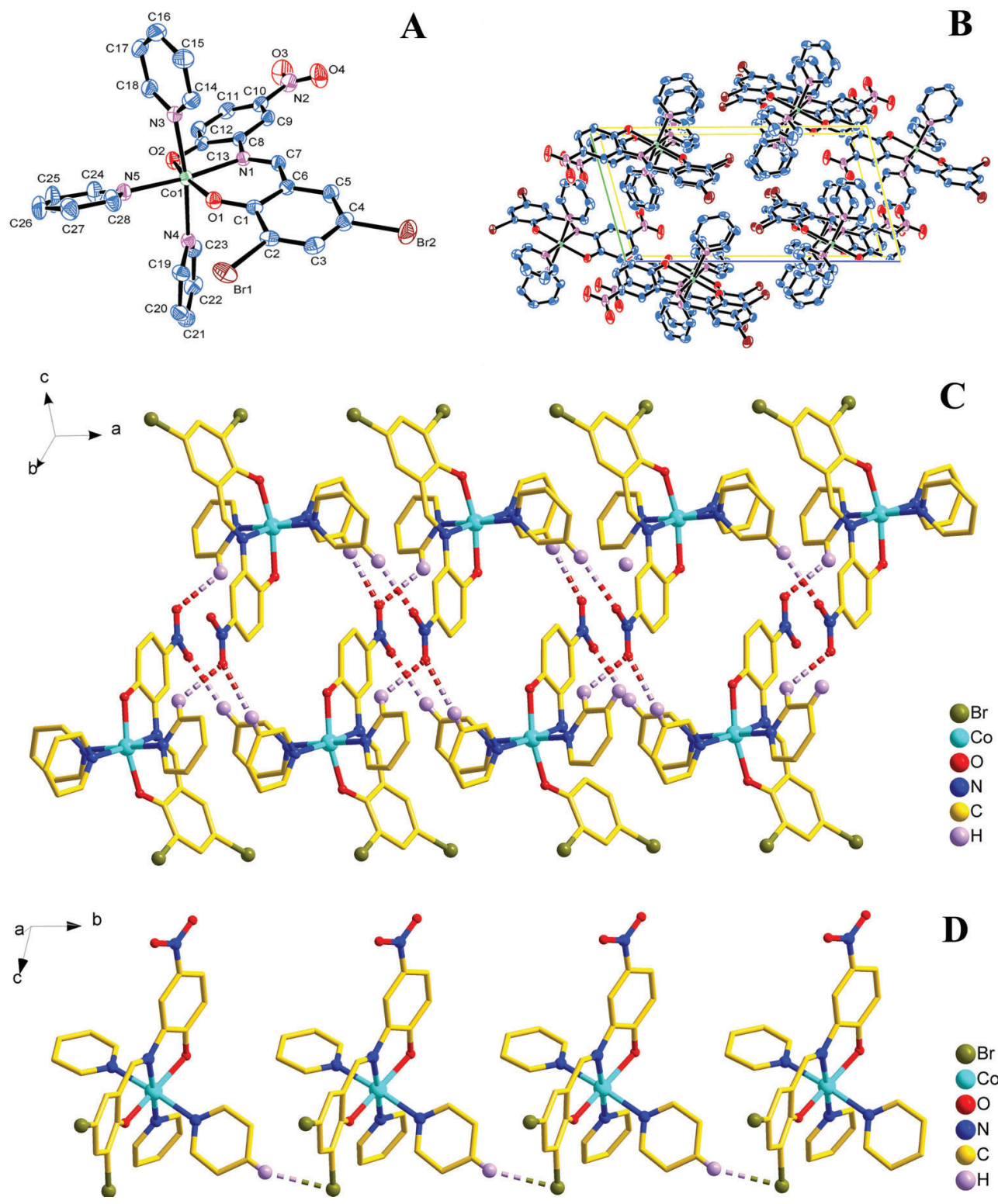

Figure 3. $A$, Molecular structure of compound $2\left(\mathrm{Py}_{3} \mathrm{CoL}_{2}\right) ; B$, packing of compound 2 in unit cell; $C$, 1D ribbon-like structure of compound 2 was formed by the $\mathrm{C}-\mathrm{H}$... O hydrogen bonding interaction, $D, 1 \mathrm{D}$ chain-like structure of compound 2 was formed by the $\mathrm{C}-\mathrm{H}$... Br interaction.

$\mathrm{N} 5=2.2029(18) \AA, \angle \mathrm{O} 1-\mathrm{Co} 1-\mathrm{N} 3=93.85(6)^{\circ}, \angle \mathrm{O} 2-\mathrm{Co} 1-\mathrm{N} 3=$ $92.48(7)^{\circ}, \quad \angle \mathrm{O} 1-\mathrm{Co} 1-\mathrm{N} 5=86.86(6)^{\circ}, \quad \angle \mathrm{O} 2-\mathrm{Co} 1-\mathrm{N} 5=88.57$ $(7)^{\circ}$; for 2, Co1-O1=2.0157 (19) $\AA$, Co1-O2=2.0610 (19) $\AA$, Co1-N3=2.217 (2) $\AA$, Co1-N4=2.207 (2) $\AA$, $\angle$ O1-Co1-N3= $93.81(8)^{\circ}, \quad \angle \mathrm{O} 2-\mathrm{Co} 1-\mathrm{N} 3=92.92(9)^{\circ}, \quad \angle \mathrm{O} 1-\mathrm{Co} 1-\mathrm{N} 4=86.66$ $(8)^{\circ}, \quad \angle \mathrm{O} 2-\mathrm{Co} 1-\mathrm{N} 4=88.39(9)^{\circ}$ ], so the central Co1 atom is six-coordinate in a distorted octahedral geometry in the complexes 1 and 2 .

The packing of the compounds 1 and 2 in unit cell is shown in Figures 2B and 3B, respectively. Moreover, for 1 , the $\pi \ldots \pi$ and $\mathrm{C}-\mathrm{H} \ldots \mathrm{O}$ interactions were observed between adjacent molecules, which led to the formation of an interesting 1D chain structure (Figure 2C). The $\mathrm{C}-\mathrm{H} \ldots \mathrm{Cl}$ interaction in an adjacent molecule also resulted in the formation of a 1D chain structure (Figure 2D); for 2, the C$\mathrm{H}$... O Hydrogen bonding interactions $[\mathrm{H} 17$... O4 2.5939 (29)

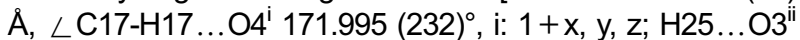
2.5571 (30) A, $\angle \mathrm{C} 25-\mathrm{H} 25 \ldots \mathrm{O}^{\mathrm{ii}} 136.210$ (306) ${ }^{\circ}$, ii: 2-x, 2-y,

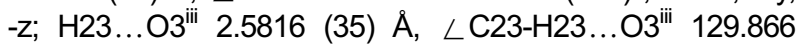
$(196)^{\circ}$, iii: 1-x, 2-y, -z;] were observed between adjacent molecules, which led to the formation of an interesting 1D ribbon-like structure (Figure $3 \mathrm{C}$ ). The $\mathrm{C}-\mathrm{H} . . . \mathrm{Br}$ interaction 
Table 2. Antiproliferative activity $\mathrm{IC}_{50}(\mu \mathrm{M})$ of $\mathrm{Py}_{3} \mathrm{CoL}_{1}$ (1) and $\mathrm{Py}_{3} \mathrm{CoL}_{2}$ (2) and their corresponding organic ligands $P y, L_{1}$ and $L_{2}$.

\begin{tabular}{lccc}
\hline Compounds & \multicolumn{3}{c}{$\mathrm{IC}_{50}(\mu \mathrm{M})$} \\
\cline { 2 - 4 } & $\mathrm{A}-431$ & $\mathrm{HT}-144$ & SK-MEL-30 \\
\hline $\mathrm{Py}$ & $114.5 \pm 6.2$ & $120.5 \pm 6.1$ & $117.5 \pm 4.9$ \\
$\mathrm{~L}_{1}$ & $93.2 \pm 7.1$ & $94.9 \pm 6.9$ & $98.8 \pm 7.0$ \\
$\mathrm{~L}_{2}$ & $90.8 \pm 3.5$ & $112.6 \pm 5.3$ & $111.7 \pm 5.9$ \\
1 & $11.3 \pm 2.7$ & $17.8 \pm 3.1$ & $19.8 \pm 4.8$ \\
2 & $16.3 \pm 1.8$ & $17.1 \pm 2.1$ & $17.4 \pm 2.6$ \\
Doxorubicin $^{*}$ & $0.158 \pm 0.067$ & $0.141 \pm 0.061$ & $0.180 \pm 0.041$ \\
\hline
\end{tabular}

Data are reported as means \pm SE of 3 independent experiments performed in duplicates. $\mathrm{IC}_{50}$ : Drug concentration required to inhibit tumor cell proliferation by $50 \%$ after continuous exposure of $48 \mathrm{~h}$. *Doxorubicin was used as positive control.

$\left[\mathrm{H} 21 \ldots \mathrm{Br} 1^{\mathrm{i}} 2.8754\right.$ (4) $\AA, \angle \mathrm{C} 21-\mathrm{H} 21 \ldots \mathrm{Br} 1^{\mathrm{i}} 149.139(227)^{\circ}$, $\mathrm{i}: \mathrm{x}, 1+\mathrm{y}, \mathrm{z}]$ in an adjacent molecule also resulted in the formation of a 1D chain-like structure (Figure 3D).

\section{Antitumor activity}

The tumor cell growth inhibition activities of 1,2 and their corresponding organic ligands $P y, L_{1}$ and $L_{2}$ were assessed in vitro on 3 human skin cancer cell lines (A-431, HT-144, and SK-MEL-30) after continuous exposure for $48 \mathrm{~h}$. The results were compared to the antiproliferative effects of the reference control doxorubicin. All compounds were dissolved in DMSO at $1 \mathrm{mg} / \mathrm{mL}$ immediately before use and diluted just before addition to the cell culture.

Data are reported as means \pm SE of 3 independent experiments performed in duplicate (Table 2). The antiproliferative activity of the test compounds against each of the title tumor cell lines may be arranged in a descending order according to the measured concentration required to inhibit tumor cell proliferation by $50 \%\left(\mathrm{IC}_{50} \mu / \mathrm{M}\right)$. From the results, we can see that compounds 1 and 2 showed significant growth inhibition activity on the 3 tumor cell lines $\left(\mathrm{IC}_{50}=11.3 \sim 19.8 \mu / \mathrm{M}\right)$, compared to their corresponding organic ligands $P y, L_{1}$ and $L_{2}\left(I_{50}=90.8 \sim 120.5 \mu / M\right)$.

In conclusion, we successfully obtained two new Co(II)-coordination compounds (1 and 2) by employing two different flexible Schiff base ligands. From the biological activity investigation, we observed that the antitumor activity of compounds 1 and 2 advanced greatly when organic ligands pyridine and Schiff bases were in coordination with Co ion. However, additional studies are needed to define the mechanism underlying this antitumor activity and evaluate the drug efficacy in vivo.

\section{References}

1. Borisova NE, Reshetova MD, Ustynyuk YA. Metal-free methods in the synthesis of macrocyclic Schiff bases. Chem Rev 2007; 107: 46-79, doi: 10.1021/cr0683616.

2. Guo XK, Sun HP, Shen S, Sun Y, Xie FL, Tao L, et al. Synthesis and evaluation of gambogic acid derivatives as antitumor agents. Part III. Chem Biodivers 2013; 10: 73-85, doi: $10.1002 / c b d v .201200126$.

3. Götz M, Wortmann P, Schmid S, Hugel T. A multicolor single-molecule FRET approach to study protein dynamics and interactions simultaneously. Methods Enzymol 2016; 581: 487-516, doi: 10.1016/bs.mie.2016.08.024.

4. Chen Y, Bian Y, Sun Y, Kang C, Yu S, Fu T. Identification of 4-aminoquinoline core for the design of new cholinesterase inhibitors. Peer J 2016; 4: e2140, doi: 10.7717/peerj.2140.

5. Diedrich B, Rigbolt KT, Röring M, Herr R, Kaeser-Pebernard $S$, Gretzmeier C, et al. Discrete cytosolic macromolecular BRAF complexes exhibit distinct activities and composition. EMBO J 2017; 36: 646-663, doi: 10.15252/embj.201694732.

6. Han R, Sun Y, Kang C, Sun H, Wei W. Amphiphilic dendritic nanomicelle-mediated co-delivery of 5-fluorouracil and doxorubicin for enhanced therapeutic efficacy. $J$ Drug Target 2017; 25: 140-148, doi: 10.1080/1061186X.2016. 1207649.

7. Al-Harbi SA, Bashandy MS, Al-Saidi HM, Emara AA, Mousa TA. Synthesis, spectroscopic properties, molecular docking, anti-colon cancer and anti-microbial studies of some novel metal complexes for 2-amino-4-phenylthiazole derivative. Spectrochim Acta A Mol Biomol Spectrosc. 2015; 145: 425439, doi: 10.1016/j.saa.2015.03.054.

8. Ryckbosch SM, Wender PA, Pande VS. Molecular dynamics simulations reveal ligand-controlled positioning of a peripheral protein complex in membranes. Nat Commun 2017; 8: 6, doi: 10.1038/s41467-016-0015-8.

9. Greiss F, Kriegel F, Braun D. Probing the cooperativity of binding networks with high-throughput thermophoresis. Anal Chem 2017; 89: 2592-2597, doi: 10.1021/acs.analchem. $6 \mathrm{~b} 04861$.

10. Sheldrick GM. SHELXL-97. Program for crystal structure solution and refinement. Götingen: University of Götingen; 1997. 